\title{
RESISTÊNCIA, CONFLITOS E COSTUMES NA BAHIA ESCRAVISTA SOB O OLHAR DA HISTORIA SOCIAL
}

\author{
THE SOCIAL HISTORY AND THE RESISTENCE, CONFLICTS AND CUSTUMS \\ IN SLAVERY BAHIA
}

Valéria Amim (Autora) ${ }^{1}$

\author{
Lismar Lucas Santos dos Reis(Coautor) ${ }^{2}$
}

\begin{abstract}
Resumo: Objetiva-se discutir questões relacionadas ao negro e seus processos de resistência na Bahia do Século XIX, apresentadas sob a ótica da recente historiografia brasileira, uma vez que a escravidão marcou expressivamente os contornos da sociedade colonial e é refletida hoje de inúmeras maneiras por meio das relações raciais, desigualdades sociais e culturais. Com isso pretende-se refletir sobre aspectos do cotidiano da população escravizada, sua capacidade de negociar, de se mobilizar e de se expressar segundo seus valores religiosos e culturais. Utilizando-se de fragmentos de algumas obras de historiadores como Stuart Schwartz, João Reis, entre outros, buscouse descrever algumas características fundamentais que são perceptíveis sob a ótica da história vista "de baixo” ao analisar, em específico, os desdobramentos históricos de duas regiões: o Sul da Bahia e Salvador, apontando uma perspectiva de compreensão mais ampla da história do Brasil em resposta às consequências teóricas e sistêmicas trazidas pela escravidão.
\end{abstract}

Palavras-chave: Sul da Bahia; Salvador; Resistência escrava.

Abstract: This paper aims to discuss questions about the Brazilian black people and their processes of resistance in Bahia in the XIX century. We approach the discussing considering the perspective adopt by the recent Brazilian historiography, since the slavery marked significantly the contours of the colonial culture and is reflected nowadays, in many scopes, through the racial relations, social and culture inequality. By these means, we intent to reflect about the aspects of enslaved people's daily life, their ability to negotiate, mobilize, and to express themselves according their religious and cultural values. Using fragments of some books written by historians like Stuart Schwartz, João José Reis and others, we intended to describe some fundamental aspects that are noticeable in "History from bellow" point of view analyzing the historical unfolding of two regions: the south of Bahia and Salvador, bringing forward a wider perspective of Brazilian history's comprehension in response to the theories consequences brought by slavery.

Key words: South of Bahia; Salvador; Slavery resistance.

Os mais de 300 anos de escravidão negra e seus desdobramentos são temas de trabalhos produzidos tanto pela historiografia brasileira quanto pelos chamados “brasilianistas”, historiadores estrangeiros que mergulharam nos documentos no intuito de contribuir para a construção da

1 Doutora em Cultura e Sociedade pela Faculdade de Comunicação da Universidade Federal da Bahia - UFBA, Salvador, BA. Professora titular do Curso de Comunicação Social no Departamento de Letras e Artes - DLA da Universidade Estadual de Santa Cruz - UESC, Ilhéus, BA. Pesquisadora do Núcleo de Estudos Afro-Baianos Regionais - KÀWÉ/NEABs da Universidade Estadual de Santa Cruz - UESC e coordenadora do projeto de pesquisa "A tradição Ijexá no Sul da Bahia".

2 Graduando em História (Licenciatura) pela Universidade Estadual de Santa Cruz - UESC, Ilhéus, BA. Bolsista de Iniciação Científica no projeto de pesquisa "As interfaces entre as práticas religiosas e as manifestações culturais: os quilombos de Itacaré, BA" (2017-2018) no Núcleo de Estudos Afro-Baianos Regionais - KÀWÉ/NEABs, orientado pela professora doutora Valéria Amim. 
narrativa histórica brasileira. Um marco divisório para os estudos voltados à escravidão deu-se a partir do centenário da abolição. Neste sentido, temos bem marcados dois períodos distintos: os estudos produzidos anteriormente ao centenário e aqueles influenciados pela nova historiografia brasileira após 1988.

Essa atenção voltada ao período entre $1538^{3}$ e 1888 se explica pelas singularidades da escravidão brasileira e, principalmente, por suas formas de resistência, tendo em vista que o sistema escravista fez parte da vida cotidiana brasileira pelo menos até a segunda metade do século XIX. Entretanto, cabe ressaltar que tal destaque começou a ser dado pelos historiadores somente em meados do século passado, em especial, os influenciados pela História Social Inglesa. Conhecida como “A História Vista de Baixo”, essa corrente historiográfica teve sua ascensão na Inglaterra e se espalhou pelo mundo em poucos anos. O Marxismo, sua principal influência no método de análise das sociedades, trouxe uma visão diferente sobre quais deveriam ser os sujeitos estudados pela historiografia, e são justamente aqueles negligenciados pelas tendências historiográficas anteriores: os escravizados, os vencidos, os excluídos, os explorados.

A história do Brasil começou então a ser reescrita sob uma nova ótica. Os trabalhos historiográficos anteriores, por sua vez, evidenciavam uma relação de poder unilateral, representando o sujeito escravizado como um ser que não se organizava e resistia para mudar a realidade na qual estava inserido, apresentando, na maioria das vezes, descrições folclorizadas das tradições africanas no estudo da vida dos escravos. Todavia, situações adversas apontam para um contexto situado entre um comportamento passivo e agressivo: o de negociação. Este viria a imprimir um novo modo de vida singular, mediado por experiências, tradições culturais e religiosas compartilhadas entre os escravos e os forros frente à classe de senhores. Além disso, é preciso compreender que os negros escravizados, ainda, sofreram a influência das constantes mudanças que ocorriam na estrutura social vigente, próprias de uma Colônia que emergia, além de viverem “[...] sob a pressão cultural do europeu branco, católico e da dupla política seguida pelo Estado português, representado por seus governadores, e da Igreja Católica, representada por seus monges [...]” (BASTIDE, 1971, p.32).

Devido aos trabalhos historiográficos recentes que versam sobre a cidade de Salvador e a Região Sul da Bahia, esses territórios são hoje conhecidos mundialmente por conta de suas peculiaridades no que diz respeito às relações escravistas que neles se estabeleceram. Nesse texto analisaremos a percepção de alguns eventos específicos que tomaram destaque nos escritos de grandes historiadores e deixaram claro que a Bahia foi marcada pelos mais diversos tipos de

3 A primeira leva de escravos desembarcados no Brasil data do ano de 1538, segundo Pantoja e Saraiva (1999). 
situações particulares no contexto da escravidão. Foram eles o levante negro do Engenho de Santana em 1789; a devassa do Quilombo do Oitizeiro em 1806 - ambos no Sul da Bahia -, a invasão do Candomblé Accú em 1829, a trajetória de vida do ex escravo Domingos Sodré e a revolta da Cemiterada em 1836 - na cidade de Salvador.

Nessa nova perspectiva, historiadores como Stuart Schwartz e João José Reis se destacaram ao priorizarem análises sobre esses desdobramentos históricos. Em seus escritos sobre o Brasil escravista e as singularidades das relações imersas em seu interior, Reis demonstra uma exímia capacidade de tornar clara sua linha de pesquisa e seu método de análise histórica. Tendo como orientador em seus cursos de mestrado e doutorado o historiador brasilianista Stuart Schwartz, é possível perceber algumas semelhanças na forma como ambos constroem uma narrativa sobre o cenário da escravidão brasileira. As práticas intermediárias que se colocam entre um comportamento de agressividade e de passividade do sujeito escravizado são um grande exemplo dessas semelhanças, além disso, percebe-se nessas análises a forte presença de uma natureza africana, especialmente, na cultura escrava baiana.

O Engenho de Santana em Ilhéus, por exemplo, aparece, ora com grande destaque ora tímido, recorrentemente nas obras de ambos como um espaço que presenciou as mais diversas formas de resistência à escravidão. Mas, essas formas de resistência não se expressavam apenas através da fuga ou do embate físico, as sabotagens e o corpo mole eram mais recorrentes do que se imagina. Em sua trajetória sui generis, o Santana foi palco de uma grande contestação do que era definido pela ideologia escravista. Um exemplo claro é a disposição territorial do próprio engenho, no qual a moradia dos escravos se localizava em um morro íngreme, longe da visão do administrador, além disso, as portas se mantinham trancadas, o que favorecia as recorrentes “fugas noturnas”. Percebe-se também nas relações entre senhores e escravos, o caráter paternalista, além do incentivo ao casamento entre escravos e a formação de famílias, pensado especialmente como uma forma de suprimir gastos com o cuidado dos escravos, já que, se um escravo caísse doente, haveriam pessoas que poderiam cuidá-lo, sem a necessidade de uma mobilização da casa grande, e também a presença de uma botica com medicamentos no engenho, no intuito de atender casos que precisassem de uma maior assistência. Tal fato reflete o interesse dos senhores de escravo em mantê-los vivos e ativos no trabalho, afinal um escravo a menos significava prejuízos na produção. Entretanto, há relatos de que os escravos souberam extrair grandes proveitos desses benefícios, uma vez que,

[...] descobriram serem os problemas físicos e psicológicos uma das mais eficazes formas de fugir das organizações da vida na propriedade. Cativas menstruadas não só não lidavam 
com água, segundo o costume geral, mas também não trabalhavam ou iam à missa e às vezes ficavam na cama por duas ou três semanas. As mulheres que haviam dado à luz recentemente, os escravos que tinham um dente extraído ou que se recuperavam de uma doença recusavam-se, todos, a assistir à missa, alegando que o "cheiro dos mortos" era-lhes prejudicial (SCHWARTZ, 1988, p. 329).

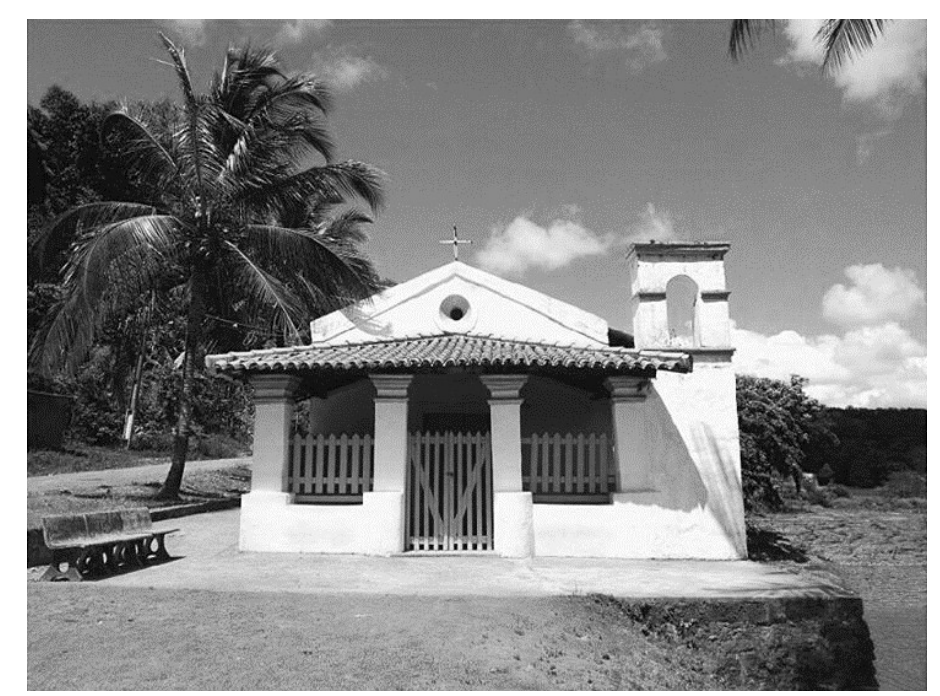
século XVII

Figura 1: Fotografia atual da Igreja de Nossa Senhora de Santana construída no Engenho de Santana durante o

A resistência à escravidão, a formação e a defesa de comunidades de escravos fugitivos se estabeleceram em resposta ao sistema escravista. Reis, tal qual Schwartz, afina o debate historiográfico ao introduzir as peculiaridades da escravidão no processo de formação social brasileiro, insertando uma abordagem que não reduz os acontecimentos à oposição estrutural entre senhores e escravos, constante nas análises anteriores sobre a resistência escrava no Brasil. Observa que os cativos forjaram uma particular sabedoria política, alcançando espaços de negociação no interior de uma sociedade escravista. Segundo Reis “[...] o escravo africano soube dançar, cantar, criar novas instituições, e relações religiosas e seculares, enganar seu senhor, às vezes envenená-lo, defender sua família, sabotar a produção, fingir-se doente, fugir do engenho, lutar quando possível e acomodar-se quando conveniente” (1983, p.107).

A natureza intrínseca na relação de negociação entre senhores e escravos demonstra subliminarmente "espaços sociais” produzidos pelos escravos, além de destacar recorrentemente, a centralidade da mão de obra escrava na economia e no sistema social e cultural vigente no Brasil. Como bem sabemos a escravidão não se rompia nas porteiras das fazendas ou dos engenhos, ao contrário, se constituía inserida na lei geral de propriedade, e neste sentido, compunha uma ordem socialmente aceita. O que significa pensar, que era a sociedade escravista, impregnada com seus ideais, seus valores, com sua maneira de perceber a realidade, e imprimindo formas de ser e de se 
fazer presente, claramente no seio social, o grande obstáculo às fugas e insurreições. Reis situa claramente essa forma “de estar e ser”, vigente no sistema escravista colonial, como paradigma ideológico colonial (REIS, 1989, p.66).

A economia colonial, baseada na mão de obra escrava, insere ao debate sócio histórico o protagonismo não só de senhores, mas, sobretudo, dos escravos, inserindo em um ambiente de violência, intransigências, de trabalho disciplinado, um espaço social tecido ora por barganhas e negociações, ora por conflitos, insurreições e fugas. Neste sentido, como bem situa Schartz “[...] os escravos não formavam uma comunidade igual a qualquer outra. Eles eram uma força de trabalho, e os trabalhos forçados prestados a outros orientavam praticamente todos os aspectos da sua situação" (SCHWARTZ, 2001, p. 89). Eram, pois, as quebras de compromissos, e acordos anteriormente firmados entre senhores e escravizados, a principal motivação para as revoltas. Outrossim, os castigos corporais, intrínsecos ao paradigma ideológico colonial pesaram menos como fator determinante das revoltas e fugas do que a ruptura dos acordos ou de costumes já estabelecidos. Estas rupturas instigaram fortes reações coletivas, inserindo nesses “espaços sociais”, a negociação como uma forma de retorno ao trabalho dentro do complexo negociação/resistência. Reestabelecer antigas normas de trabalho, que implicavam diretamente com os direitos já adquiridos, esteve na raiz de revoltas, levantes e fugas, demonstrando que “[...] existia em cada escravo ideias claras, baseadas nos costumes e em conquistas individuais, do que seria, digamos, uma dominação aceitável” (REIS, 1989, p. 67), o que incitou recorrentemente espaços sociais de negociação, entre essas, a chamada "brecha camponesa" que nada mais era que uma das formas de controle e manutenção da ordem, desenvolvidas pelo sistema escravista.

Os estudos no Brasil sobre esse aspecto, entretanto, esbarram no pensamento tradicional da historiografia que via nas negociações, e por assim dizer, na chamada "brecha camponesa", uma atitude de liberalidade por parte dos senhores, uma vez que os escravos enquanto propriedade de outrem ou mesmo como instrumentos de produção, não teriam uma economia própria. Com o intuito de melhor compreendermos tal fenômeno é preciso darmos conta de que o controle e a vigilância perpassam as atividades cotidianas da fazenda escravista. Implica compreender que “o imperativo de organizar, controlar e aumentar a produtividade do trabalho escravo foi maior do que a preocupação em conservar as plantações” (REIS, 1989, p.27). A “brecha camponesa” consistia na cessão de um pedaço de terra (em usufruto), por parte do senhor, ao escravo, e a folga semanal para que esta terra fosse trabalhada. Desta maneira, o senhor aumentava a produção de gêneros alimentícios que eram necessários à escravaria, além de oportunizar ao cativo uma forma de escapar 
das pressões resultantes da escravidão. Esta abordagem sobre a "brecha camponesa" é uma dentre as mais variadas formas de pensar e denominar a economia própria dos escravos dentro das fazendas. A documentação existente no século XIX refere-se exaustivamente sobre a questão da segurança, destacando, neste sentido, uma preocupação maior com as revoltas e insurreições. Tanto assim, que 1854 os cafeicultores do atual município de Vassouras no Rio de Janeiro, reuniram-se e recomendaram um conjunto de seis medidas "prudentes e moderadas” que deveriam ser adotadas em todas as fazendas. As três primeiras eram repressivas: a proporcionalidade entre pessoas livres e escravas; armas correspondentes ao número de pessoas livres; manter vigilância constante dos escravos. As demais medidas não apelavam diretamente para força, mas, principalmente, para ideologia: “[...] permitir e mesmo promover divertimento entre os escravos (...) quem se diverte não conspira; promover por todos os meios o desenvolvimento das ideias religiosas; e finalmente, "permitir que os escravos tenham roças e se liguem ao solo pelo amor a propriedade; o escravo que possui nem foge, nem faz desordens” (REIS, 1989, p.29).

Por fim, cabe ainda dizer que a "brecha camponesa” não se constituiu como a única forma de prover uma economia aos cativos, uma vez que estes forjaram outras possibilidades de remuneração. Todavia, ela cumpriu, sobremaneira, seu papel como mecanismo de controle e regulação da força de trabalho da escravaria. Além disso, nenhum sistema até os dias de hoje viabilizou-se apenas por meio da força e da violência, não seria o sistema escravista, portanto, uma exceção.

Um dos mais emblemáticos eventos de levante negro que teve o Engenho de Santana, situado em Ilhéus, Bahia como palco foi à rebelião escrava em 1789. Os escravos, durante o período em que se encontravam levantados, propuseram e encaminharam à administração do engenho, um tratado de paz como instrumento de negociação e retorno ao trabalho. O referido tratado continha 19 exigências ordenadas segundo seus principais interesses. Eram demandas muito claras, e ao mesmo tempo reveladoras, tanto em seus conteúdos quanto em suas omissões e silêncios. Na análise de um documento histórico nos diz Reis é preciso considerar que “[...] um documento vale, naturalmente apenas pelo que diz, mas também por suas ausências e por seus silêncios” (REIS, 1989, p. 67). Das 19 exigências, 13 se dirigiam ao trabalho, e as demais diziam respeito à economia interna dos escravos, demonstrando o desenvolvimento de estratégias para alcançar espaços de autonomia e de melhores condições de vida. Nesse sentido, o documento se torna singular ao desvelar o protagonismo dos escravos no agenciamento da história, com habilidades para expressar seus interesses por meio de reivindicações, que via de regra, transcorriam sob pressões e conflitos, 
tencionando, assim, mudanças no regime que os oprimia (REIS, 1989; SCHWARTZ, 2001).

Os negros escravizados exigiam a concessão das terras alagadas para o plantio de alimentos para subsistência, entre outras reivindicações, como a possibilidade de “(...) brincar, folgar, e cantar em todos os tempos que quisermos, sem que nos empeça, e nem seja preciso licença” (REIS, 1983, p. 124). Apesar de malsucedido, o levante e o tratado de paz representaram, sob a ótica de alguns historiadores, um marco no surgimento de movimentos sociais que emergiram em situações de contradição do modelo de produção colonial, além de serem fontes importantes para demonstrar o poder de negociação e a força da população escrava quando seus interesses eram colocados em jogo.

Entre as várias expressões de resistência, a formação dos quilombos foi uma das mais importantes. Apesar de estarem situados em "lugares protegidos”, as comunidades quilombolas, na maioria das vezes se encontravam nas proximidades dos engenhos, fazendas, vilas e cidades, na fronteira da escravidão, onde era possível manter laços e criar uma rede de apoio e interesses que envolvia escravos, negros livres e mesmo brancos, de quem recebiam informações sobre a circulação das tropas e outros assuntos estratégicos relacionados à guarda e defesa das comunidades. Afirma Reis “[...] com essa gente eles trabalhavam, se acoitavam, negociavam alimentos, armas, munições e outros produtos; com escravos e libertos podiam manter laços afetivos, amigáveis, parentais e outros” (1995-96 p.18). Dessa maneira, Reis (1995) rompe com a ideia de isolamento e autossuficiência dos quilombos. Com relação à sua formação populacional, ele chama atenção para a diversidade dos sujeitos que convergiam para os quilombos: embora houvesse uma predominância dos africanos e seus descendentes, havia soldados desertores, aqueles perseguidos pela justiça secular e eclesiástica, vendedores, índios ou simples aventureiros. O que exigiu, em certa medida, de seus habitantes um olhar diferenciado sobre as diferenças, afim de que novos laços de solidariedade fossem forjados e culturas pudessem ser recriadas nos Quilombos.

Um exemplo significativo desta condição foi o Quilombo do Oitizeiro situado em Itacaré, Sul da Bahia. A história desse quilombo evidência uma tessitura entre as comunidades quilombolas de Itacaré ${ }^{4}$. Ela integra a memória coletiva dessas comunidades fornecendo elementos na explicação e compreensão de suas realidades e histórias, influenciando as relações sociais, inclusive parentais entre as linhagens ancestrais. Os quilombolas de Itacaré se reconhecem também como uma dispersão do Oitizeiro após sua devassa. Segundo a descrição:

O quilombo do Oitizeiro estava localizado nas imediações da vila de Barra do Rio de

4 Atualmente 5 comunidades são reconhecidas pela Fundação Palmares, são elas: Fojo, Serra de Água, João Rodrigues, Santo Amaro e Porto de Trás, este último reconhecido como quilombo urbano. 
Contas (atual Itacaré), onde fora instalado fazia talvez alguns anos, sem que providências tivessem sido tomadas para combatê-lo. No início de maio de 1806, o governador deu início a seu plano para assaltar o Oitizeiro. [...] A operação foi fulminante e bem-sucedida. Além de assaltar, prender e dispersar os moradores do Oitizeiro, os soldados palmea-ram a região atrás de negros fugidos entre fins de junho de 1806 e início de março de 1807. [...] porém, a devassa feita para investigar o quilombo do Oitizeiro revelaria uma comunidade que não se encaixava no modelo convencional de agrupamento de negros fugidos. No local viviam pequenos lavradores de mandioca com seus escravos e tanto estes como aqueles recrutavam quilombolas para trabalharem em suas respectivas lavouras. Isso era o quilombo. Ou seja, senhores e escravos, os moradores permanentes do Oitizeiro, agiam como coiteiros e empregadores de negros fugidos, que trabalhavam em regime de meação nos mandiocais e na produção da farinha, que era vendida para o mercado local, como também para Salvador e seu Recôncavo. Parte da farinha servia para abastecer os numerosos navios negreiros que àquela altura atravessavam o Atlântico continuamente em busca de novos braços para a escravidão brasileira. Tínhamos então no Oitizeiro um quilombo peculiar, integrado à economia regional e, mesmo, atlântica, onde convivia uma variedade de tipos sociais, além de escravos em fuga do jugo de seus senhores. Alguns desses escravos, ademais, empreendiam uma fuga temporária com o objetivo de procurar novos senhores que os comprassem dos atuais, estes, sem dúvida, por eles considerados despóticos além do suportável. Assim, se o conde da Ponte desembarcou na Bahia com um modelo idealizado de quilombo em mente, ao ler a devassa do Oitizeiro entenderia que a situação era mais complicada, pois os escravos, mesmo na resistência, não estavam isolados, mas participavam de redes às vezes sólidas de interesses com setores livres da sociedade (REIS, 2008, p.109).

A história oficial do Oitizeiro desvela as relações que existiam entre o quilombo e a sociedade. Tais relações se afastam daquelas tradicionalmente relatadas nas histórias difundidas por modelos consagrados, como "Palmares", no qual as comunidades se rebelavam contra escravidão, fugiam e se organizavam longe do local onde eram mantidos como escravas e escravos. Definitivamente, no Oitizeiro, a vida circulava em torno das negociações advindas das relações socioeconômicas que sustentavam a economia da vila, subsidiada pelo cultivo da mandioca, cuja produção estava integrada ao mercado regional. Vale ressaltar que isto não invalida a existência e manutenção da prática escravocrata nessa região, no entanto, suas diversas roupagens sugerem e representam muito mais do que costumeiramente se reproduz.

A terra ocupada pelos quilombolas que viviam no Oitizeiro, em quase sua totalidade, pertencia ao lavrador Balthasar da Rocha, considerado o principal coiteiro ${ }^{5}$ na devassa ocorrida em 1806. Escravizados de diversas localidades fugiam e uniam-se aos deste quilombo que armados podiam se defender dos rastreadores e capitães do mato. As tensões decorrentes dessas relações de trabalho e seus desdobramentos sugerem, de um lado, uma alternativa para o maior

5 Couto (ou coito) compreende-se por terra coutada ou aquela onde se podiam asilar os criminosos, onde não entrava a justiça do rei (em Portugal e no Brasil-Colônia). A variação "Coiteiro" aplicada no nordeste brasileiro, significa, segundo Ferreira: "aquele que dá coito, [homízio], [refúgio] ou asilo a bandidos [ou alguém de reputação suspeita]" (2000 p. 162). 
desenvolvimento da produção de farinha da família Rocha que, segundo a testemunha T9 da devassa “davam todo auxílio aos negros fugidos” (REIS; GOMES, 1996, p. 354), de outro, evidencia o aspecto libertário do povo negro que tencionou a criação de um modelo nãoconvencional de escravidão, o que certamente modificava a sua qualidade de vida. O que indica e Reis (1996) desconfiava disso, que os negros escravos não se furtavam à condição de cativos, mas, sim, buscavam um novo senhor que lhes oferecesse as mesmas condições que eles desfrutavam no Oitizeiro. "[...] eles tinham suas visões da escravidão tanto como da liberdade. Neste caso, a liberdade de escolher a escravidão" (REIS; GOMES, 1996, p. 358).

A região Sul da Bahia, em especial, fora marcada por acontecimentos emblemáticos no que se refere aos atos de resistência à escravidão, tais como o levante do Santana e o Quilombo do Oitizeiro já citados. Entretanto, a memória hegemônica local foi reescrita pela classe dominante durante o período de ascensão da monocultura do cacau, o que trouxe uma representação de apagamento e negação da presença do negro na história regional, inclusive no trabalho da lavoura cacaueira. É certo que o incremento da cultura cacaueira se diferenciou das áreas cafeeiras do Vale do Paraíba ou do oeste paulista, principalmente, por ser seu quantitativo de cativos inferior ao utilizado naquelas áreas. Todavia, os indicadores da escravidão na cultura do cacau, acrescido da presença da aristocracia baiana em sua formação, mostram que em Ilhéus, assim como em outras partes da Bahia e do Brasil, antes de 1888, a relação com o trabalho se dava da seguinte maneira: sempre que possível, deve ser feito primeiramente pelos escravos (AMIM, 2009, p. 107). Mesmo que em número menor, como afirma Mahony (2001, p. 96):

\begin{abstract}
Alguns plantadores de cacau tiveram, efetivamente, acesso a escravos, e os consideravam muito importantes. Isto não significa que todos os fazendeiros de cacau tenham possuído escravos, nem que a escravidão tenha sido a única forma de mão-de-obra empregada no sul da Bahia no século XIX. Mas significa, sim, que escravos estiveram presentes em Ilhéus, e trabalhando no cacau — assim como em outras culturas — ao longo de todo o século XIX.
\end{abstract}

Além do mais, esses cativos em Ilhéus viriam conservar, apesar do contexto desfavorável, antigos costumes, como manifestações musicais e coreográficas de diversos tipos, várias delas marcadas por uma forte religiosidade. Dito isso, a historiografia recente sobre a região traz como objetivo o descortinamento de narrativas históricas já estabelecidas e a disputa hegemônica da memória regional, inserindo o negro como protagonista na construção de sua própria história e na forja da cultura do Sul da Bahia.

Mergulhar profundamente nos relatos históricos nos quais a negociação se sobrepôs, se 
antecedeu, ou se sucedeu ao conflito direto, demonstra algumas situações em que a violência pura e simples estava longe de ser um caminho viável na relação entre o senhor de escravo e o sujeito escravizado, a exemplo da invasão do Candomblé do Accú na cidade de Salvador em 1829.

A invasão ao Candomblé nos mostra alguns fatos inusitados, passíveis de diálogo, inclusive com vestígios encontrados em distintas fontes sobre outros lugares e momentos históricos distintos, para concluir que as concessões, ações paternalistas e os fracassos nas tentativas de segregação entre brancos, libertos, pretos e crioulos $^{6}$ era algo recorrente no sistema escravista brasileiro. Além disso, a dominação cotidiana do senhor, e da sociedade em geral para com o escravo, era rompida por meio da rebeldia, influência pessoal e autonomia cultural. Vale ressaltar que no decorrer da primeira metade do século XIX, forjou-se na Bahia um ambiente favorável à resistência escrava. Como em outros lugares nos quais se deu a escravidão, as etnias africanas foram autodenominadas de "nações", e 60\% dos escravos e libertos faziam parte delas. Os pardos, e mesmo os negros nascidos no Brasil, formavam um contingente de $40 \%$ da população da cidade (REIS, 1989). Essa forte representatividade de negros africanos na Bahia favoreceu uma singular representação cultural, ao mesmo tempo em que forjavam suas identidades étnicas, além de uma diferenciada disposição de lutar, reivindicar e negociar. O grande número de escravos africanos na cidade provocava preocupação e tensão na classe senhorial que se encontrava inserida em um ambiente social, político e cultural intenso, e em recorrente movimentação.

Foi nesse contexto que se deu a invasão do Candomblé de Accú, situado nas imediações da cidade de Salvador, em meados de 1829. Essa violação realizada pela polícia, caso analisada sem a devida cautela, poderia significar só mais um caso de intolerância direcionada a um dos grupos de Candomblé de nação jeje que existiam em Salvador naquela época. Entretanto, algo chama a atenção no desfecho de toda essa trama: o fato do juiz Antônio Guimarães, que autorizou a investida ao terreiro, ser obrigado pelo presidente da província da Bahia a se retratar sobre o incidente. Segundo o próprio juiz, o incômodo causado pela festa no terreiro que já durava três dias, estava pautado por fatores muito pontuais: a reunião nos Candomblés representava elementos políticos de rebelião escrava que se misturava ao fato de que “[...] o ajuntamento de 'gente de várias cores’ em uma festa significava desordem social” (REIS, 1989, p. 44), sem esquecer-se da ousadia dos escravos, da permissividade dos senhores e da complacência das autoridades.

6 Cabe observar a designação que separava a população negra entre os africanos, chamados de pretos, e os negros nascidos no Brasil, chamados de crioulos. É importante enfatizar também o caráter de paternalista que segregava “os escravos nascidos aqui, supostamente confiáveis, e os aguerridos escravos arrancados da África” (REIS, 1989, p. 45). 
Apesar de toda justificativa, o fantasma das rebeliões negras pairava durante o século XIX, e a astúcia do africano Joaquim que, em um claro jogo político, denunciou o assalto no terreiro ao presidente da província, José Gordilho de Barbuda, foram determinantes para que as explicações por parte do juiz se fizessem necessárias. A invasão ao Candomblé traz à tona toda uma constante correlação de forças em relação às práticas religiosas no complexo repressão/permissão, demonstrando que a invasão do Accú pelas autoridades policiais e seu desfecho inusitado, representavam um aspecto de grande peso e recorrência, muitas vezes esquecido pela historiografia sobre a escravidão brasileira.

A análise da invasão ao Candomblé do Accú faz emergir elementos importantes sobre o papel do Candomblé como instituição central de representação e negociação dos negros na Bahia, o que corrobora com a ideia de que o terreiro representava para além de um local de culto, um espaço de resistência cultural e de pertencimento, fundamental à análise da vida cotidiana do negro, principalmente na Bahia. A repressão ao Candomblé se relacionava, sobretudo, ao papel protagonizado pela religião, que tanto revelava seu conteúdo de objeção à escravidão, quanto suas características de resistência cultural, social e religiosa. O que mostra que a religião não acontecia, pois, separada da vida social, ao contrário, assim como no país dos ancestrais, ela estava em estreita relação com o cotidiano da comunidade.

As bases ideológicas e religiosas que vigoravam sob a vigência do paradigma colonial, eram antagônicas à religião e aos costumes dos escravos e dos negros libertos. Neste sentido, os historiadores em um exercício da micro-história, puderam explorar o ponto de vista dos escravos, no estudo do Candomblé como forma de resistência cultural. Utilizando a história de vida e a biografia de sacerdotes que viviam na Bahia do século XIX, Reis (2008) nos apresenta a biografia de Domingos Sodré, um ex-escravo que vivia na cidade de Salvador, em um contexto cujas relações sociais associavam-se as esferas de poder, as atividades econômicas e culturais presentes no cotidiano dos libertos, que na terceira margem $^{7}$ do sistema escravista, negociavam alguns espaços de autonomia. No caso de Domingos, tais espaços permitiram a ele atuar como sacerdote e adivinho. Ao descortinar a vida de Domingos, o historiador realiza uma análise sobre a formação do Candomblé na Bahia do século XIX, apresentando-nos todo o aparato policial da Bahia oitocentista na repressão e combate às práticas culturais dos negros, incluindo o batuque, mas, especialmente o Candomblé. Todavia, o perigo representado pelo candomblé tal como sua supressão, revelava, ainda, um conflito entre as autoridades. O que deixa subentendido que entre as políticas de

7 A terceira margem nos remete a invenção de se permanecer, de meio a meio, adentro, a fora, ao mesmo tempo indo solto, ao largo. Horizontes coisificados no mundo, homens lançados à margem de qualquer possibilidade. 
repressão e permissão no que tangia as práticas religiosas de matriz africana à época, sempre foram questões delicadas e complexas. Como narra o autor, "[...] as autoridades policiais com frequência se desentendiam” (REIS, 2008, p. 25), gerando para subdelegados acusações de permissividade no tocante ao som dos tambores que soavam alto nos candomblés sob seus olhos e ouvidos, além do som se espraiar aos moradores das redondezas.

Outro aspecto que torna singular o caráter biográfico de Domingos é a ruptura com os modelos clássicos das biografias, com histórias de vida cronológicas, com previsibilidade e linearidade do início ao fim. Domingos Sodré ininterruptamente entra e sai da narrativa, levandonos a questionar em qual lugar ele se encontra? O caráter lacunar das fontes bem como a falta de documentação historiográfica ou documental sobre a vida de Domingos, estão diretamente relacionados ao silêncio dos arquivos sobre a "vida dos de baixo", o que torna Domingos ao mesmo tempo personagem principal e anônimo da história. Reis deixa explícita sua opção em Domingos operar como uma metonímia de seu tempo, conforme a micro história italiana, cujas biografias se relacionam à reconstituição de microcontextos ou a personagens extremos, normalmente anônimos, despercebidos pela sociedade. Neste sentido, o personagem Domingos descentra-se e dispersa-se em dezenas de personagens que ocupam o seu lugar na narrativa. Por um lado, essa substituição se dá sempre que as informações sobre Domingos se escasseiam, por outro, a substituição atua como metáforas do velho sacerdote, em que diferentes rostos, corpos e situações, dispersam o ser singular, único, tornando-o um ser exemplar, sujeito e síntese de seu tempo, de sua cultura e da sociedade. Dessa maneira, a dispersão num primeiro momento, transforma-se, posteriormente, em unificação e homogeneização para encarnar a situação do liberto no século XIX, na Bahia. Tais lacunas encontradas pelo historiador ao narrar à vida deste ex-escravo, permitiram a ele lançar mão da imaginação, da ficção, de supor o que teria sido, de tentar imaginar a vida de Domingos e de outros tantos negros libertos, seus companheiros de condição na cidade da Bahia, em determinada data e em tal situação. Esse ato de ficcionar se dá, entretanto, pelo conhecimento que o historiador possui do período que estuda além daquilo que conhece sobre o movimento da cultura e da sociedade. Sem essa capacidade de imaginar, ficcionar e desenrolar a narrativa imprimindo-lhe sentidos e significados para aquilo que o passado deixou de rastros e que chega até o presente, a historiografia não seria possível (ALBUQUERQUE JUNIOR, 2009).

Sabe-se há algum tempo, e os historiadores são os que mais se deparam com as lacunas e os vazios dispostos nos documentos encontrados, que eles nem sempre dizem tudo, e que a comprovação de certos fatos e acontecimentos descritos em suas teses, muitas vezes díspares, se 
relacionam mais com os significados atribuídos pelo historiador após sua leitura do que com os dados encontrados em si.

A reflexão posta por Reis ao lermos a narrativa de Domingos Sodré remete-nos a clareza e a consciência que ele possui sobre a construção da narrativa histórica. Ao afastar-se da visão clássica e totalizadora, e por vezes ingênua, de que é possível uma construção histórica definitiva dos eventos e de seus personagens e, que essa seria em última instância, a verdadeira versão do passado (ALBUQUERQUE JUNIOR, 2009) -, ele nos mostra a narrativa construída no presente, pelo historiador que, via de regra, utiliza em sua construção informações que chegaram do passado. Assim, remove-se o véu que revestia a construção da narrativa histórica clássica, destacando a construção textual do historiador na realização da história.

Os levantes, as revoltas e a percepção “dos de baixo” se entremeiam a cartografia da sociedade baiana do século XIX, desvelando práticas que dizem respeito tanto a religiosidade quanto aos costumes desencadeados pelas atividades socioculturais, a exemplo das práticas funerárias de seus habitantes.

A revolta popular ocorrida em outubro de 1836 ocasionou em Salvador, a destruição do cemitério do Campo Santo, recém-inaugurado. Participaram da revolta, distintos segmentos da população que puderam valer-se da complacência da polícia local. O levante que ficou conhecido como a "cemiterada”, foi a resposta popular à proibição da realização de rituais fúnebres e enterros de cadáveres nas igrejas da cidade, como era costume (FIGURA 2), e a concessão de monopólio funerário a uma companhia privada por 30 anos. A consistência histórica presente no evento nos possibilita observar de distintos ângulos o fato ocorrido.

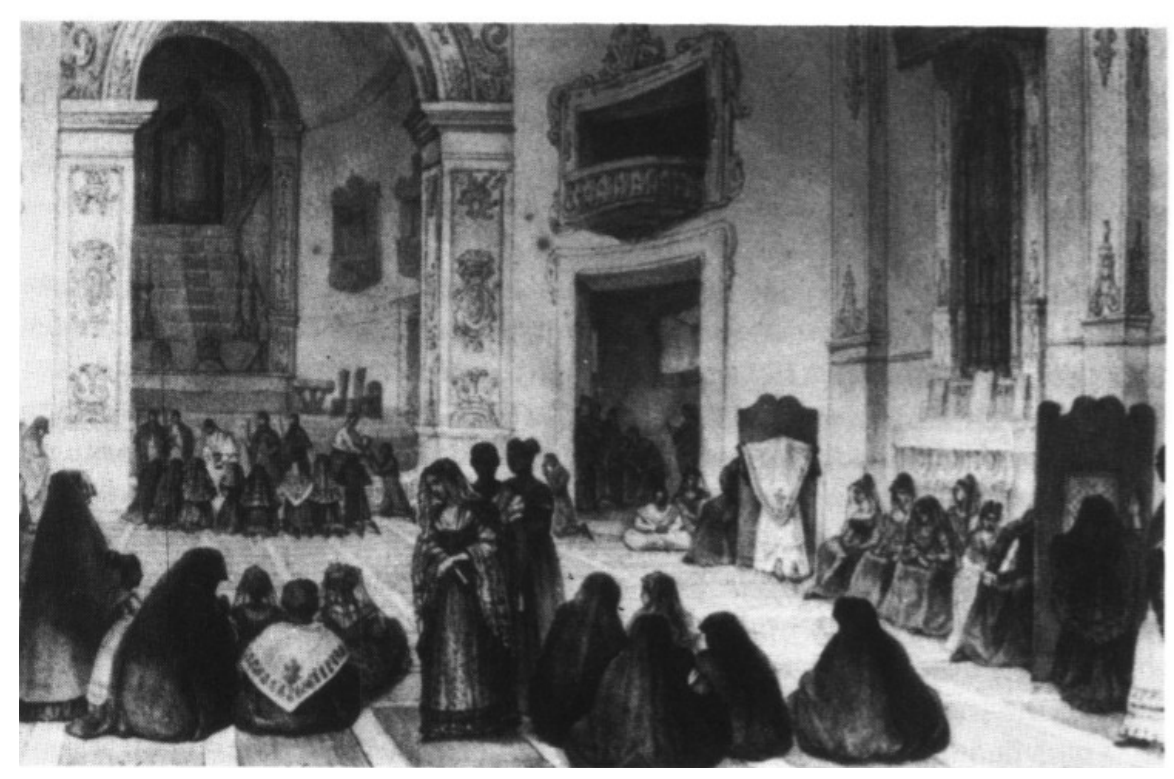


Figura 2: Pintura intitulada Fieis se acomodam sobre sepultura nas igrejas (Debret, Voyage Pittoresque, III, prancha 31).

Na resistência contra o cemitério, as tensões sociais estão postas de um lado pelos interesses econômicos e, de outro pelo confronto de mentalidades. Para melhor compreensão do levante “cemiterada”, faz-se necessário destacar o papel das Irmandades de negros ${ }^{8}$. A tendência associativa nos negros “[...] transbordou dos quilombos para as próprias cidades, constituindo-se religiosamente a seu modo, no respeito, porém, aos princípios católicos da colonização portuguesa” (GUERRA, 1970, p.111). É por meio das Irmandades que podemos compreender os modos de articulação do tecido social vigente, recuperando, ainda, as especificidades dos ritos festivos promovidos por essas associações. É possível perceber que nos rituais das Irmandades coexistiam antigas tradições portuguesas e africanas que reafirmavam o aspecto lúdico do catolicismo colonial brasileiro, despertando o velho culto aos santos, ao mesmo tempo em que se colocava na contramão da Reforma Religiosa. Suas repercussões se estenderiam aos domínios dos símbolos, dos valores e dos ideais religiosos, permitindo uma maior aglutinação e acomodação simbólica das manifestações africanas. No interior das Irmandades, observa-se uma persistência da lógica de legitimação simbólica dos valores africanos, apesar desta lógica conviver intensamente com a visão europeizante da morte.

$\mathrm{Na}$ sociedade ampla, a atitude das autoridades oscilava entre a repressão e a permissividade. A tentativa dos poderes político e econômico em controlar a legitimação da vida simbólica em sua totalidade convergia com as concepções sanitaristas da morte, norteando dessa maneira, as políticas públicas desde então. A festa e o funeral possuíam características análogas, com momentos de solidariedades e distanciamentos bem marcados entre brancos e negros, trabalhadores, libertos e a dos senhores. Período no qual somente os escravos e indigentes eram enterrados distante das igrejas, o que sugeria a existência de uma cartografia social do morto.

Ao tratar sobre as atitudes do homem frente à morte, observa-se um debate coevo sobre o bem morrer europeu, o processo de mutação das sensibilidades, orientado pela racionalidade burguesa que passava a criticar enterro dentro das igrejas e nos cemitérios contíguos. Refutava-se em síntese a proximidade física entre vivos e mortos (REIS, 1991).

A adesão popular imprimiu ao levante um caráter multiclassista e plurirracial, sem nenhuma

8 As irmandades religiosas tiveram uma significativa importância na expansão do catolicismo na América Portuguesa, reunindo leigos em torno da devoção à um santo ou santa, além de prestarem serviços de ajuda mútua que iam desde a realização das festas, a promoção de cerimônias de enterramento, e auxílio aos irmãos necessitados (doentes, presos, cativos). Funcionavam em acordo com um conjunto de regras chamadas de compromissos que deveriam ser aprovados pela Igreja Católica, Presidente de Província e pela autoridade monárquica. 
exclusão de cor ou de status social. A apreensão das tensões forjadas pelo processo de centralização e construção do Estado Imperial, no que se refere a gestão e controle da vida cotidiana, nos é revelada em meio a uma conjuntura da história política e cultural, evidenciando a sobreposição e a circularidade entre imaginário e prática social, incluindo suas relações de força.

O debate e as reflexões proporcionados pela história social e a micro-história sejam no tratamento da escravidão, sejam quando abordam os levantes ou quilombos, nos trazem uma história de outras vozes, as vozes dos “de baixo”, do anônimo, daqueles negligenciados pela história tradicional como sujeitos. A inclusão dos “de baixo” na construção da história, reafirma posicionamentos políticos e uma postura ética desses historiadores frente à escravidão, ao mesmo tempo em que eles põem em xeque a naturalização da posição ocupada por negros e negras na sociedade hoje, explicitando as desigualdades sociais e raciais, o racismo sistêmico, e mais recentemente, o racismo virtual, protegido pelo anonimato da internet, e que veicula todos os ódios, incluindo à seara, o ódio racial. Esses historiadores fizeram a opção por povoar em suas narrativas históricas, os escravos, suas fugas, seus quilombos (urbanos e rurais), suas crenças, sejam elas em Alá, em Olorum ou Zambi, em Oxalá ou Senhor do Bonfim, em Ogum ou Inkôssi ou Santo Antônio. Encontramos, ainda, aqueles escravos que negociavam uma vida menos opressiva, que acumulavam bens e compravam sua alforria ou de outros que se encontravam numa mesma condição, bem como senhores e governantes mais maleáveis ou senhores e governantes mais severos.

Nos documentos tratados pela historiografia social os sujeitos possuem nomes, subjetividade e subvertem a ideia de passividade frente à máquina escravista, mesmo quando se percebe um silêncio, uma lacuna, ou uma interpretação enviesada da realidade. Nas obras literárias e ou históricas encontramos Bilal Licutan, Luiz Sanin, Manoel Calafate, João Maloni, Francisco e Francisca Cidade, Zeferina, Gregório Luis, Gangazuri, protagonistas à frente das revoltas escravas ocorridas na Bahia. O liberto malê alufá Rufino José Maria, cozinheiro e pequeno traficante de gente de um navio negreiro; o sacerdote Domingos Sodré que fornecia beberagens aos escravos para acalmar seus senhores, mas era ele próprio dono de escravos e Manoel Joaquim Ricardo um liberto haussá que prosperou e que fazia parte dos $10 \%$ mais ricos de Salvador, entre outros. Homens e mulheres que foram retirados do anonimato, forjando trajetos individuais que nos permitem uma nova compreensão da sociedade brasileira, ainda hoje crivada por tensões e preconceitos entre estratos sociais e complexos culturais distintos.

Ancorados em fatores como o parentesco, as irmandades, as práticas religiosas, entre outros 
contextos, os negros africanos, se inventaram, recorrentemente, em termos de "nações” e de “identidades” entre outros arranjos, articulando-se numa extraordinária cidade atlântica, parafraseando Gomes. “Corpos, línguas e mentes eram remarcados permanentemente em termos sociais e étnicos. Símbolos, marcas, penteados e outros sinais ganhavam, mantinham, mudavam ou perdiam significado” (GOMES, 2005, p.48). A “criação” de identidades e formas culturais seria, dessa maneira, muito mais afetada pelos contextos, pelas experiências da escravidão e da pósemancipação, do que propriamente pelas origens étnicas.

Essas construções foram fundamentais para que se formassem novos arranjos sociais e se criassem instituições originais, inclusive religiosas, conservando, adaptando e recriando uma parte importante dos valores e das tradições que não se deixaram desaparecer na experiência da escravidão.

\section{REFERÊNCIAS BIBLIOGÁFICAS}

ALBUQUERQUE JUNIOR, Durval Muniz. João José Reis. Domingos Sodré, um sacerdote africano: escravidão, liberdade e candomblé na Bahia do século XIX. Revista brasileira de história. São Paulo, v.29, nº 57, p. 211-2017.

AMIM, Valéria. AMIM, Valéria. Águas de Angola em Ilhéus: um estudo sobre as construções identitárias no Candomblé do sul da Bahia. Programa Multidisciplinar de Pós-Graduação em Cultura e Sociedade - UFBA. Tese de Doutorado, 2009.

BASTIDE, Roger. As religiões africanas no Brasil. Primeiro volume. São Paulo: Livraria Pioneira Editora; Editora da Universidade de São Paulo, 1971.

GUERRA, Flávio. Velhas igrejas e subúrbios históricos. Recife: Fundação Guararapes, 1970.

GOMES, Flávio dos Santos; FARIAS, Juliana Barreto \& Soares, Carlos Eugênio Líbano (2005). No labirinto das nações: africanos e identidades no Rio de Janeiro, século XIX. Rio de Janeiro, RJ: Presidência da República, Arquivo Nacional.

MAHONY, Mary Ann. Instrumentos necessários escravidão e posse de escravos no sul da Bahia no séc. XIX, 1822-1889. Afro-Ásia, 25-26, (2001, p.95-139).

PANTOJA, Selma e SARAIVA José Flávio Sombra (org.). Angola e Brasil: nas rotas do Atlântico Sul. Rio de Janeiro: Bertrand, 1999.

REIS, João José; SILVA, Eduardo. Negociações e conflito: a resistência negra no Brasil escravista. São Paulo: Companhia das Letras. 1989.

REIS, João José. A morte é uma festa: ritos fúnebres e revolta popular do século XIX. São Paulo: 
Companhia das Letras, 1991.

- Domingos Sodré, um sacerdote africano: escravidão, liberdade e candomblé na Bahia do século XIX. São Paulo: Companhia das Letras, 2008.

. O Don[o] da Terra chegou, Cento e cincoenta acabou: Notas sobre resistência e controle dos escravos na Bahia, que recebeu a família real em 1808. REVISTA USP, São Paulo, n.79, p. 106117, setembro/novembro 2008.

SCHWARTZ, S. Segredos internos: engenhos e escravos na sociedade colonial. São Paulo: Companhia das Letras. 1988.

. Escravos, roceiros e rebeldes. São Paulo: EDUSC, 2001. 